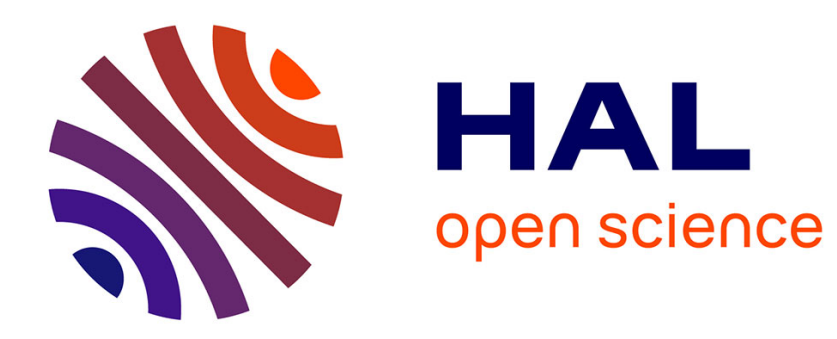

\title{
New observations on the Bandkeramik house and social organization
}

\author{
Lamys Hachem
}

\section{To cite this version:}

Lamys Hachem. New observations on the Bandkeramik house and social organization. Antiquity, 2000, 74. hal-02964089

\section{HAL Id: hal-02964089 \\ https://hal.science/hal-02964089}

Submitted on 14 Oct 2020

HAL is a multi-disciplinary open access archive for the deposit and dissemination of scientific research documents, whether they are published or not. The documents may come from teaching and research institutions in France or abroad, or from public or private research centers.
L'archive ouverte pluridisciplinaire HAL, est destinée au dépôt et à la diffusion de documents scientifiques de niveau recherche, publiés ou non, émanant des établissements d'enseignement et de recherche français ou étrangers, des laboratoires publics ou privés. 


\title{
New observations on the Bandkeramik house and social organization
}

\author{
LAMYS HACHEM*
}

The careful study of faunal and artefact remains associated with Bandkeramik houses in France has shown new details about activity zones and village organization in the Early Neolithic. Lamys Hachem describes the result of work from Cuiry-lès-Chaudardes in the Aisne valley, France.

Key-words: Linearbandkeramik, Neolithic, houses, faunal remains, France, Aisne valley

The people who settled in central and western Europe at the beginning of the Neolithic were farmers living in villages composed of longhouses. These structures were made of wood and daub, but all that remains today are post-holes, wall foundation trenches, refuse pits alongside the walls and other pits further away from the houses.

Research into the earliest Neolithic of Europe has always shown great interest in how these domestic units functioned (Soudsky 1969; Modderman 1970; Boelicke 1982; Lüning 1982; Milisauskas 1986; Coudart 1989; 1993; Hodder 1990). Analysis of a number of recently excavated sites in the Paris basin has produced some new data on this research issue. The main results come from Cuiry-lès-Chaudardes (Aisne, France), dating to the late Linearbandkeramik (Lbk), and Jablines (Seine-et-Marne, France), dating to the subsequent, Lbk-related, Villeneuve-SaintGermain group. The period involved is approximately $5000-4800 \mathrm{BC}$.

The new data from these sites provide a preliminary response to several questions, notably concerning the distribution of finds in the lateral pits and the function of the household and its place within the village.

\section{The site of Jablines: houses and original neolithic occupation surface}

At Jablines, near Paris, an excavation covering 2500 sq. m produced two houseplans. The original Neolithic occupation surface was preserved as a layer roughly $10 \mathrm{~cm}$ thick, which could be compared with the underlying and contemporary subsoil features (Bostyn et al. 1991). Sev- eral thousand artefacts were recovered (around $85 \mathrm{~kg}$ of ceramics, $380 \mathrm{~kg}$ of lithic finds and $500 \mathrm{~kg}$ of animal bone), the occupation layer representing just over $72 \%$ of the total weight of finds. The dispersal of finds within this layer is far from uniform. The principal deposits are concentrated outside the houses in the areas along the side walls, reflecting the position and main use of the lateral pits. However, some finds are located within the rear part of the buildings (Lanchon et al. 1997: 6). This rear sector, which corresponds to the western third of the houseplans, produced evidence for specific activities, indicated by the presence in situ of complete vessels, as well as waste of a more general nature. Similar observations have been made in the Villeneuve-Saint-Germain settlement at Echilleuses in the Loiret département (Simonin 1996, 1997). Other areas within the houses at Jablines produced insignificant numbers of finds, suggesting a closed domestic space where debris was regularly collected and then dumped outside. Zones of high artefact density were observed well outside the houseplans, corresponding for example to temporary flint-working areas behind the western, back end of the houses. By contrast, there are very few finds from the area in front of the east end of the buildings, traditionally considered to be the main access zone.

Analysis of household activities has been made in two famous Linearbandkeramik sites where the original Neolithic soil has disappeared, in Germany (Aldenhoven Plateau) and in Poland. Study of the finds in the pits (which did not preserve animal bones) around the

\footnotetext{
* UMR 7041 (Protohistoire européenne), Laboratoire d'Archéozoologie, Centre Archéologique, Abbaye St Jean-desVignes, 02200 Soissons, France.
}

Received 20 November 1998, accepted 18 February 1999, revised 1 March 2000. 
houses suggest that at Langweiler 8 the northern area of the house was associated with lithic artefacts (Boelicke 1982; 1988), and that at Olszanica some human activities were spatially segregated by gender (Milisauskas 1986; 1989). At the recently discovered 'Petit Paradis' site in Belgium, pit containing thousands of lithics and few other finds will also provide new informations about household activities (BurnezLanotte \& Allard 1998).

The situation outlined above for Jablines clearly indicates the amount of material lost on sites without preserved occupation surfaces. However, at Jablines similar kinds of artefact occur in both the occupation layer and the subsoil features, and this is particularly the case with the lithic finds (Bostyn 1994). This would suggest that, on sites where the original occupation surface has disappeared through erosion, the preserved sample of finds remains unaffected in qualitative terms, since the range of artefacts is not fundamentally modified. This conclusion is encouraging for the validation of analyses of the material from the vast majority of sites where the finds have only survived in features dug into the subsoil.

\section{Cuiry-lès-Chaudardes: the most important Lbk faunal sample from 33 houses}

Further analysis of the distribution of finds from pit contexts has been conducted at the Linear Pottery site of Cuiry-lès-Chaudardes (Hachem 1995a; 1997). This settlement has been completely excavated and covers an area of 6 ha, with 33 houseplans. Here, small groups of houses were successively built over a period of 150-200 years (Ilett et al. 1982; 1986). The relative chronology of the houses is based on ceramic decoration, and the site can be divided into five settlement phases with an average of six houses per phase. The houseplans are quite widely spaced and all have lateral pits. The bones from the pits are particularly well preserved. This site has produced the largest sample of faunal remains currently known for the whole Bandkeramik culture $(49,778$ bone fragments, excluding sieving). The number of bone fragments per house (i.e. from the lateral pits of each house) varies considerably, from 10 to almost 7000 fragments. The minimum volume of waste per house has been evaluated at about 10 $\mathrm{kg}$ (approximately 1000 bones). Smaller quantities of bone are probably explained by differential preservation of features, through deep ploughing or earlier erosion: The larger quantities of faunal remains may be related to house size. Excluding the six houses with extreme counts (the lowest and highest numbers), variation in quantity by house does remain significant, as the standard deviation shows. The average of 1386 bones per house must therefore be taken only as a broad indication of the quantities involved.

Sieving has been rarely used on the Aisne valley excavations, because of the very extensive surface areas dealt with every year under rescue conditions. In order to estimate potential loss of faunal remains due to the absence of sieving, a comparative study was undertaken on three lateral pits next to houses at Cuirylès-Chaudardes (Hachem 1995a: table 13). One square metre out of two was hand excavated, usually by trowel, and the other was wet sieved. Some interesting results emerge from this study. In quantitative terms, the proportion of finds recovered by sieving may seem important (4949 bone fragments), but $98 \%$ of the bones from sieving are unidentifiable splinters of less than $1 \mathrm{~cm}$, originating from disintegration of bone surfaces or from burnt household waste. In qualitative terms, the identifiable fragments provide additional information on the smallest species such as fish, birds and amphibia, and on the smallest anatomical parts of other species, such as phalanges of small game. Interesting as this information may seem, the number of identifiable fragments is minute, compared to the number of bones recovered without sieving. The great length of time that would be involved in systematic sieving of thousands of cubic metres of sediment thus seems excessive in relation to the results which, furthermore, have only a limited effect on species representation in the sample. This is confirmed by work on lithic material from sieved residues on the same site by M. Plateaux (ERA 12/CNRS), and on faunal remains from sieving at another settlement in the Aisne valley at Bucy-le-Long (K. Bolen, UCLA, pers. comm.). The loss in quantity and quality of information due to the absence of systematic sieving is of minor importance compared to the benefits derived from the excavation of large areas, without which the broader context would not of course be understood.

\section{Spatial distribution of finds}

Further examination of the spatial distribution of faunal remains at Cuiry-lès-Chaudardes has 
revealed quantitative differences between the lateral pits on the north and south sides of each house (Hachem 1995a; 1997: 251). Each house shows a tendency to discard faunal material on one side rather than the other, and in some cases on one side exclusively. This situation is clarified when the settlement phases are taken into account, suggesting the existence of neighbourhood rules: pairs of contemporary houses (associated chronologically) typically discard their bone waste on opposite sides. The symmetric principle underlying waste distribution is also apparent for the lithic finds (Plateaux 1993: plate XLI), since the lateral pits which contain over $60 \%$ of the flint artefacts of a given house also produce the maximum quantities of bone. The social interpretation of this structural opposition of waste disposal can be linked to two factors: the way the space was used inside the house and secondly the neighbouring house whose physical disposition was taken into consideration.

Another phenomenum appears to be systematic in these Bandkeramik villages: the existence of concentrations of finds in recurrent, precise locations within the lateral pits (Chataignier \& Plateaux 1986; Ilett et al. 1986; Constantin 1995; Hachem \& Auxiette 1995; Simonin 1997). The main concentration occurs in the southern pit near the 'corridor' (two closely set rows of posts marking the western end of the central part of the house), but there are also concentrations on the northern side (FIGURE 1). This spatial distribution seems to suggest the presence in the side walls of openings (doors or windows), although these cannot be detected on the groundplans themselves.

Interpretation of the quantitative variation in faunal remains between houses is still problematic. Is this related to differences in the length of time the pits were open, or is it linked to the number of occupants per house ? While it is not yet possible to resolve these problems, certain data of a qualitative nature nevertheless offer a partial response. For example, variation observed between houses at Cuiry-lèsChaudardes in the relative frequency of domestic and wild animals cannot be explained by differences in the use-lives of pits. The list of seasonal markers (trophy antlers and the kill-off. pattern for cervidae which includes very young animals) for 25 houses indicates 56 cases between spring and autumn (April-November) and 29 for the winter (December-March). These determinations thus seem to indicate that the pits of each house were accumulating refuse for at least one year (Hachem 1995a: 159).

\section{Small houses and large houses in a spatially structured village}

What is found in these pits? The total sample from Cuiry-lès-Chaudardes $(15,795$ identified bones) represents 20 species, approximately $80 \%$ of which are domestic animals (Hachem 1997: 252). Three kinds of livestock (cattle, sheep and pig) are systematically present in the pits of each house, as are two wild species (red deer and aurochs). Apart from these species, wild boar and roe deer are quite common, and beaver is the most frequent small animal. However, there is variation between houses and this is particularly the case with the relative frequency of hunted animals. There are two reasons for this. The first is related to chronology, since there was more hunting at the beginning of the occupation of the site than at the end. The second is linked to house types.

Typological analysis of the 33 houseplans at Cuiry-lès-Chaudardes separates the buildings into two broad categories, depending on the number of rooms behind (west of) the 'corridor' (FIGURE 1): small houses (up to $15 \mathrm{~m}$ long) with one room behind the 'corridor', and large houses (over $15 \mathrm{~m}$ long) with two or three rooms and in some cases a foundation trench (Hachem 1995a). Meat consumption is apparently related to these two architectural types. There is a relationship for example between the size of the house and the volume of bone waste discarded: the maximum values generally occur in the large houses. But a more precise relationship between faunal remains and house type can be defined. The highest values for wild animals in general (from $23.8 \%$ to $41.1 \%$ ), and in particular wild boar, occur in small houses, whereas the highest frequencies for domestic animals (from $91.3 \%$ to $96 \%$ ) come from large houses. This phenomenon has a broader relevance, for it seems to be one of the main factors explaining the differences of hunting rates in the $95 \mathrm{Lbk}$ sites of Europe that have provided enough faunal remains for analysis (Hachem 1999).

Finally, it can be argued, using the distribution of both animal bones and of buildings, that the Neolithic house was integrated within a particular conception of village space. The settlement at Cuiry-lès-Chaudardes developed from two distinct nuclei, and the analysis of faunal 

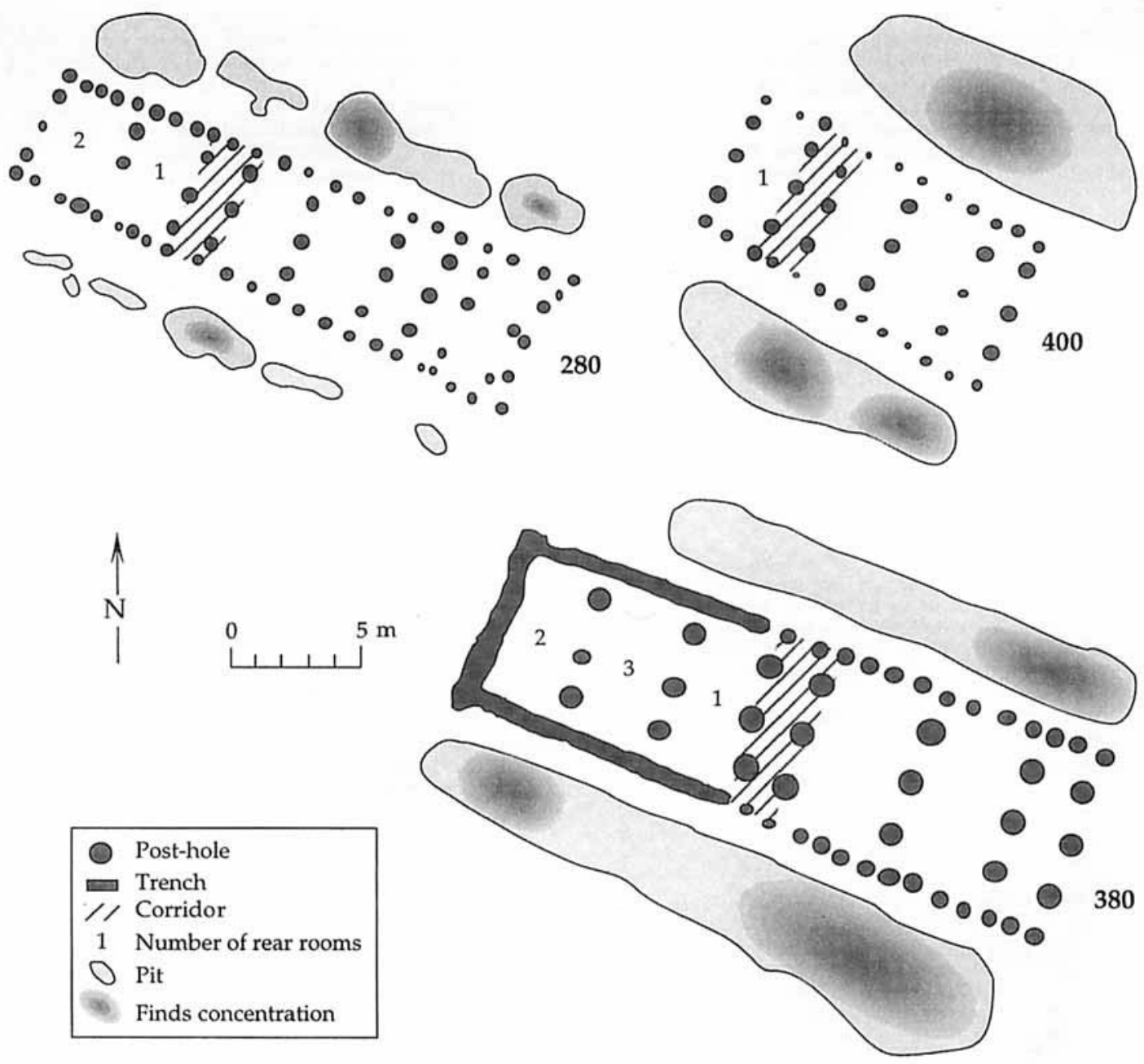

FIGURE 1. Difference of meat consumption between small and large Linearbandkeramik houses from Cuirylès-Chaudardes (excavations UMR 7041, ex ERA 12 du CNRS). The highest values for wild animals, and in particular wild boar, occur in small houses (one room behind the corridor), whereas the highest frequencies for domestic animals come from large houses (two or three rooms behind the corridor).

remains suggests the existence of a spatially structured village. On the basis of these two lines of evidence, the site can be divided into four zones (Hachem 1995a; Hachem 1997: 2567). Only the houses located in the northwest zone show a high rate of hunting, and generally speaking, three species seem linked to the zonal division, since the houses with the highest relative frequencies of cattle, sheep and wild boar are located separately by species. This pattern is maintained throughout the five settlement phases. It could be explained in social terms in the sense that the Rubané society can be composed of three main tendencies: cattle herders, sheep herders and hunters (Hachem 1997). Therefore the corresponding link between the size of the house and the fauna consumed could be established according to the social status.

All these results shed new light on domestic organization in the Linearbandkeramik, as well as opening particularly interesting perspectives for understanding the social structure of these early Neolithic communities.

Acknowledgements. I would like to thank Nada Hachem and Michael Ilett for the translation of this text. 


\section{References}

AuXIETTE, G., L. HACHEM \& B. ROBERT (ed.). 1997. Espaces physiques, espaces saciaux, dans l'analyse interne des sites du Néolithique à l'Age du Fer. Actes du $119 \mathrm{e}$ Congrès national des Sociétés Historiques et Scientifiques, Amiens, oct. 1994, Paris: CTHS.

BOELICKE, U. 1982. Gruben und Häuser: Untersuchungen zur Struktur bandkeramischer Hofplätze, in J. Pavuk (ed.), Siedlungen der Kultur mit Linearkeramik in Europa: 1728. Nitra: Koloquium Nové Vozokany 1981.

1988. Entwicklung des Siedlungsplatzes, in U. Boelicke J., D. von Brandt, J. Lüning, P. Stehli \& A. Zimmermann (ed.), Der bandkeramische Siedlungsplatz Langweiler 8: 891-958. Köln: Reinland-Verlag. Rheinische Ausgrabungen.

Bostyn, F. 1994. Caractérisation des productions et de la diffusion des industries lithiques du groupe de VilleneuveSaint-Germain. Thèse de doctorat de l'Université de Paris $\mathrm{X}$.

BOS'YN, F., L. HACHEM \& Y. LANCHON. 1991 [1998]. Le site néolithique de Jablines 'la Pente de Croupeton', (Seineet-Marne). Premiers résultats, in Actes du XVe Colloque Interrégional sur le Néolithique: 45-81. Châlons-sur-Marne: Association Régionale pour la Protection et l'Etude du Patrimoine Préhistorique, Voipreux.

BuRnEZ-LANOTTE, L. \& P. Allard. 1998. Mode de production laminaire dans le Rubané de Hesbaye au 'Petit Paradis' à Harduémont (Verlaine, Lg.): premiers résultats, in Organisation néolithique de l'espace en Europe du Nord-Ouest: 15-26. Actes du XXIIIle Colloque Interrégional sur le Néolithique, Bruxelles, Octobre 1997, Anthropologie et Préhistoire 109.

Chataigner, C. \& M. Plateaux. 1986. Analyse spatiale des habitats rubanés et informatique, Bulletin de la Société Préhistorique Française 83(10): 319-24.

Constantin, C. 1995. Etude de la répartition spatiale du matériel, in Ilett \& Plateaux (ed.): 144-56.

COUDART, A. 1989. Tradition, uniformity and variability of the architecture in the Danubian Neolithic, in Rulf (ed.): 199223

1993. De l'usage de l'architecture domestique et de l'anthropologie sociale dans l'approche des sociétés néolithiques: l'oxemple du Néolithique danubien, in $L e$ Néolithique du nord-est de la France et des régions limitrophes: 114-35. Actes du XIIIe Colloque Interrégional sur le Néolithique, Metz, October 1986. Paris: Editions de la Maison des Sciences de l'Homme, Documents d'Archéologie Française.

HACHEM, L. 1995a. La faune rubanée de Cuiry-lès-Chaudardes (Aisne, France); essai sur la place de l'animal dans la première société néolithique du Bassin parisien. Thèse de doctorat de l'Université de Paris I, Panthéon-Sorbonne.

1995b. La représentation de la chasse dans les espaces villageois rubanés de la vallée de l'Aisne (France), in L'animal dans l'espace humain, l'homme dans l'espace animal, Actes du 5e Colloque International de l'Homme et l'Animal. Geneva, November 1994, Antropozoologica 21: $197-205$.
1997. Structuration spatiale d'un village du Rubané Récent, Cuiry-lès-Chaudardes (Aisne). Analyse d'une catégorie de rejets domestiques: la faune, in Auxiette et al. (ed.): 245-261.

1999. Apport de l'archéozoologie à la connaissance de l'organisation villageoise rubanée, in $\mathrm{F}$. Breamer, $\mathrm{S}$. Cleuziou \& A. Coudart (ed.): Habitat et société, XIXe Rencontres d'Archéologie et d'Histoire d'Antibes. Antibes: APDCA.

HACHEM, L. \& G. AUXIETTE. 1995, La faune, in Ilett \& Plateaux (ed.): $128-43$.

HODDER, I. 1990. The domestication of Europe. Structure and contingency in Neolithic Societies. Oxford: Basil Blackwell.

ILETr, M., C. Constantin, J.P. DEMOUle \& A. COUdART, 1982. The late Bandkeramik of the Aisne valley: environment and spatial organisation, Analecta Prehistorica Leidensia 15: 45-61.

Ilet'I, M. \& M. Plateaux. (ed.). 1995. Le site Néolithique de Berry-au-Bac 'le Chemin de la Pêcherie' (Aisne). Paris: CNRS. Monographie du CRA 15.

Ilett', M., M. PlateauX \& A. Coudart. 1986. Analyse spatiale des habitats du Rubané Récent: problèmes actuels, in J.P. Demoule \& J. Guilaine (ed.), Le Néolithique de la France. Hommage à G. Bailloud: 131-40. Paris: Picard.

LANCHON, Y., F. BOSTYN \& L. HACHEM. 1997. L'étude d'un niveau archéologique néolithique et ses apports à la compréhension d'un site d'habitat: l'exemple de 'la Pente de Croupeton' à Jablines (Seine-et-Marne), in Auxiette et al. (ed.): $327-44$.

LüNING, J. 1982. Research into the Bandkeramik settlement of the Aldenhovener Platte in the Rhineland, Analecta Praehistorica Loidensia 15: 1-29.

Mtulsauskas, S. 1986. Early Neolithic settlement and society at Olszanica. Ann Arbor (MI): Museum of Anthropology, University of Michigan. Memoirs 19.

1989. Specialized activity areas at Olszanica, in Rulf (ed.): $233-42$.

Modderman, P.J.R. 1970. Linearbandkeramik aus Elsloo und Stein. Den Haag. Analecta Praehistorica Leidensia 3.

Plateaux, M. 1993. Les industries lithiques du Néolithique danubien dans la vallée de l'Aisne: principes d'analyse en contexte détritique. Le Néolithique au quotidien: 195206. Actes du XVIe Colloque Interrégional sur le Néolithique, Paris, nov. 1989, Documents d'Archéologie Française. Paris: Editions de la Maison des Sciences de l'Homme.

RULF, J. (ed.). 1989. Bylany seminar 1987. Collected papers. Prague: Ceskoslovenska Akademie Ved, Archeologicky Ustav.

Simonin, D. 1996. Les habitats néolithiques d'Echilleuses (Loiret). Analyse spatiale des documents archéologiques. Edition de la Fédération Archéologique du Loiret. Revue Archéologique du Loiret 21-22.

1997. Analyse spatiale d'un site d'habitat du néolithique ancien à Echilleuses (Loiret), in Auxiette et al. (ed.): 345-68.

SOUDSKÝ, B. 1969. Etude de la maison néolithiqua, Slovenska Archeologia 17: 5-96. 